\title{
Properties of Recycled Polypropylene/Chloroprene Rubber Blends: The Effects of Dynamic Vulcanisation
}

\author{
Chan Ming Yeng, ${ }^{1 *}$ Salmah Husseinsyah ${ }^{2}$ and Nurul Azra Bakaruddin ${ }^{2}$ \\ ${ }^{1}$ Centre of Engineering Programmes, HELP College of Arts and Technology, \\ 6.01 Level 1-7, Kompleks Metro Pudu, 1 Jalan Metro Pudu 2, \\ Fraser Business Park, 55200 Kuala Lumpur, Malaysia \\ ${ }^{2}$ Division of Polymer Engineering, School of Materials Engineering, \\ Universiti Malaysia Perlis, 02600 Jejawi, Perlis, Malaysia \\ *Corresponding author: chan.ming.yeng@helpcat.edu.my
}

Published online: 25 November 2016

To cite this article: Chan, M. Y. et al. (2016). Properties of recycled polypropylene/chloroprene rubber blends: The effects of dynamic vulcanisation. J. Phys. Sci., 27(3), 121-136, http://dx.doi.org/10.21315/jps2016.27.3.8

To link to this article: http://dx.doi.org/10.21315/jps2016.27.3.8

\begin{abstract}
This work examined the tensile, thermal, morphology and swelling properties of unvulcanised and dynamically vulcanised recycled polypropylene $(R P P) / c h l o r o p r e n e ~ r u b b e r(C R)$ blends at different blend ratios. The results indicated that the tensile strength and Young's modulus of both the unvulcanised and dynamically vulcanised RPP/CR blends were reduced. However, elongation at the breaking point increased with increasing $C R$ content. In contrast, the dynamic vulcanisation enhanced the tensile properties, melting temperature $\left(T_{m}\right)$, enthalpy $\left(\Delta H_{f}\right)$ and crystallinity $\left(X_{b}\right)$ in comparison with the unvulcanised $R P P / C R$ blends. The swelling percentage of the dynamically vulcanised RPP/CR blends was lower than the unvulcanised blends due to the presence of crosslinks after the dynamic vulcanisation occurred.
\end{abstract}

Keywords: Recycled polypropylene, chloroprene rubber, dynamic vulcanisation, tensile and thermal properties, swelling 


\section{INTRODUCTION}

Over the past few decades, several researchers have explored the development of new high-performance products by melt blending common polymers. This attention is because the polymer blends offer a simple and less expensive alternative to develop new types of materials that have properties that can be tailor-made to meet specific requirements. ${ }^{1}$ Blending with different polymers generally yields new materials that cannot be achieved using the individual components.

The utilisation of recycled polypropylene (RPP) as a polymer matrix material has increased significantly due to its economic advantage and reduced environmental impacts in today's society. ${ }^{2}$ As a result, blends of RPP with elastomers would offer an environmental advantage by reducing the use of a virgin thermoplastic matrix, which would cause increased $\mathrm{CO}_{2}$ footprint emissions. Moreover, the utilisation of RPPs in the blends as a substitute to the virgin synthetic thermoplastic matrix can reduce the overall cost of the material. In contrast, recycled plastics have exhibited a lower tensile strength, heat ageing and fracture properties compared to virgin polypropylene (PP). ${ }^{3}$ Although the properties of RPP are inferior to those of virgin PP, they can be enhanced by blending RPPs with elastomers without losing the economic advantages of the recycled material. $^{4}$

Chloroprene rubber (CR) or Neoprene is generally used to improve the toughness and the impact properties of thermoplastics. ${ }^{5}$ CR has exhibited some benefits such as a good inherent flame resistance, moderate resistance to oil and gasoline, excellent adhesion to fabrics and metals, good resistance to ozone and natural ageing, good resistance to abrasion and flex cracking and good resistance to alkalis and acids. ${ }^{6}$ Normally, CR is applicable in different applications including automotive parts, wire and cable jackets, general industrial parts, sponges and construction materials for buildings and public works.

In general, the thermoplastic elastomer (TPE) can be defined as a blend of thermoplastic and elastomer, ${ }^{5}$ which leads to an immiscible blend, phase separation, low interfacial interaction and poor mechanical properties. To improve the properties of this immiscible polymer blend, dynamic vulcanisation was performed to reduce interfacial tension, enhance the interaction adhesion between the two phases and decrease the size of the dispersed phase, as well as improve the basic properties of TPEs. A comparison between RPP/CR and PP/CR blends has been reported in our previous study. ${ }^{7}$ 
Dynamic vulcanisation is a process used to vulcanise the elastomer with a molten plastic during melt-mixing. ${ }^{8}$ The elastomers are vulcanised to give a particulate vulcanised elastomer phase with a stable domain morphology during the melt processing. The influence of dynamic vulcanisation on TPE is to produce compositions that have improvements in the permanent set, ultimate tensile properties, melt strength, fatigue resistance and thermoplastic processability. ${ }^{9}$ Several works have reported the effects of dynamic vulcanisation on the improvement of the properties of TPEs. ${ }^{10-12}$

In this work, RPP was blended with CR to produce a TPE through the melt blend process. The influence of dynamic vulcanisation on tensile, thermal, swelling and morphology properties was investigated.

\section{EXPERIMENTAL}

\subsection{Materials}

The RPP was supplied by Toray Plastics Malaysia Sdn. Bhd., Malaysia. The CR was purchased from Tosoh Corporation, Japan. It is a mercaptan modified general-purpose grade that has a moderate rate of crystallisation and Mooney viscosity. The curatives used for dynamic vulcanisation were stearic acid (Acid Chemical International Sdn. Bhd.), zinc oxide (ZnO) (Metroxide Malaysia Sdn. Bhd.), n-cyclohexyl-2-benzothiazole-2-sulfenamide (CBS) (Meyors Chemical Inc. Limited), tetramethyl thiuram disulfide (TMTD) (Deutschland $\mathrm{CimbH}$, Germany) and sulfur (Taiko Marketing Sdn. Bhd., Selangor). The relative amounts of the curatives were based on the weight of the $\mathrm{CR}$ of the blend ratios.

\subsection{Preparation of Unvulcanised and Dynamic Vulcanised RPP/CR Blends}

The RPP/CR blends were prepared using a Z-blade mixer at a temperature of $180^{\circ} \mathrm{C}$ and a rotor speed of $50 \mathrm{rpm}$. The RPP was melted in the mixer for $7 \mathrm{~min}$, after which the CR was added and mixed for 8 min. After mixing, curatives such as $\mathrm{ZnO}$, stearic acid, TMTD, CBS and sulfur were added and mixed for $2 \mathrm{~min}$ giving a total mixing time of $17 \mathrm{~min}$. The formulations of unvulcanised and dynamically vulcanised RPP/CR blends are shown in Table 1 . 
Table 1: The formulations of unvulcanised and dynamically vulcanised of RPP/CR blends

\begin{tabular}{lcc}
\hline Materials & $\begin{array}{c}\text { Unvulcanised } \\
\text { RPP/CR }\end{array}$ & $\begin{array}{c}\text { Dynamically vulcanised } \\
\text { RPP/CR }\end{array}$ \\
\hline Recycled polypropylene (RPP) (php) & $100,85,70,55,40$ & $100,85,70,55,40$ \\
Chloroprene rubber (CR) (php) & $0,15,30,45,60$ & $0,15,30,45,60$ \\
ZnO (\%) & - & 5 \\
Stearic acid (\%) & - & 2 \\
TMTD (\%) & - & 2 \\
CBS (\%) & - & 2 \\
Sulfur (\%) & - & 1 \\
\hline
\end{tabular}

php: parts per hundreds of total polymer

*curatives system based on weight of CR

\subsection{Compression Moulding of Blends}

Each of the RPP/CR blends were compressed into sheet form using a compression moulding machine, model GT 7014 with a temperature and pressure of $180^{\circ} \mathrm{C}$ and $170 \mathrm{~kg} \mathrm{~cm}^{-2}$, respectively. The blend samples were preheated for 8 minutes and then compressed for $6 \mathrm{~min}$. After that, the samples were subsequently cooled under pressure for $4 \mathrm{~min}$. The samples were then cut into dumbbell shapes using a Wallace dumbbell cutter.

\section{$2.4 \quad$ Tensile Properties}

Tensile strength, Young's modulus and the elongation at break were measured using an Instron Tensile Machine Model 5569, according to ASTM D638. The gauge length and crosshead speed were $50 \mathrm{~mm}$ and $50 \mathrm{~mm} \mathrm{~min}{ }^{-1}$, respectively. The tensile test was performed at $25^{\circ} \mathrm{C} \pm 3^{\circ} \mathrm{C}$. Five samples of each composition were tested, and the average values were recorded.

\subsection{Swelling Behaviour}

The swelling percentage of the specimens were measured according to ASTM D471. The dimensions of the specimens were $30 \times 5 \times 1.3 \mathrm{~mm}$. First, the specimens were weighed (initial weight) using a Mettler balance. Then, the specimens were immersed in toluene at room temperature for $72 \mathrm{~h}$. After that, the specimens were taken out from the toluene and wiped with tissue paper to remove excess toluene and then weighted again (swollen weight); the swelling percentage of the specimens was calculated using Equation 1: 


$$
\begin{aligned}
& \text { Swelling } \\
& \text { percentage }
\end{aligned}=\frac{\text { Swollen weight }- \text { initial weight }}{\text { initial weight }} \times 100
$$

\subsection{Morphology Study}

The tensile fracture surface of the specimens was observed using a scanning electron microscope (SEM), Model JEOL JSM-6460 LA. The fractured ends of the specimens were sputter-coated with a thin layer of palladium to avoid electrostatic charging during SEM examination.

\subsection{Differential Scanning Calorimetry (DSC)}

A thermal analysis of the specimens was performed out using a Perkin-Elmer Differential Scanning Calorimetry (DSC) in a nitrogen air flow of $50 \mathrm{ml} \mathrm{min}$. The specimens were heated from $20^{\circ} \mathrm{C}$ to $250^{\circ} \mathrm{C}$ with a heating rate of $20^{\circ} \mathrm{C} \mathrm{min}^{-1}$. The crystallinity of the blend $(\mathrm{Xb})$ was determined according to Equation 2.

$$
X_{b}=\frac{\Delta H_{f}}{\Delta H_{o f}}
$$

where $\Delta \mathrm{H}_{\mathrm{f}}$ is the enthalpy of fusion of the blend, and $\Delta \mathrm{H}_{\circ \mathrm{f}}$ is the enthalpy of fusion of perfectly $(100 \%)$ crystalline PP. The $100 \%$ crystalline PP homopolymer $\left(\Delta \mathrm{H}_{\circ \mathrm{f}}\right)$ value is $209 \mathrm{~J} \mathrm{~g}^{-1} .^{13}$

\section{RESULTS AND DISCUSSION}

\subsection{Tensile Properties}

Figure 1 shows the tensile strength of unvulcanised and dynamically vulcanised RPP/CR blends as a function of the blend ratios. The tensile strength of both the unvulcanised and dynamically vulcanised RPP/CR blends decreased with increasing CR content. On the other hand, the tensile strength of the dynamically vulcanised RPP/CR blends was higher than the unvulcanised RPP/CR blends. This is because the formation of crosslinks in the rubber phase enhanced the stress transfer in the blends. The dynamic vulcanisation process leads to a finer and more uniform CR dispersed phase in the RPP matrix. Consequently, the improved dispersion of the CR phase in the RPP matrix improved the tensile strength of the RPP/CR blends. Additionally, the presence of crosslinks increased 
the tensile strength of the dynamically vulcanised RPP/CR blends. Moreover, the improvement of the tensile strength was also due to the crosslinked rubber particles attaching to the RPP matrix, which increased the extent of deformation before failure. Van Dyke et al. ${ }^{14}$ claimed that the blends of dynamically vulcanised polyamide 12 (PA12)/chlorobutyl rubber (CIIR) with different curatives improved the tensile strength compared to unvulcanised blends. The same observation was also reported by Narathichat et al. ${ }^{15}$ in the dynamically cured natural rubber/PA12 blend system.

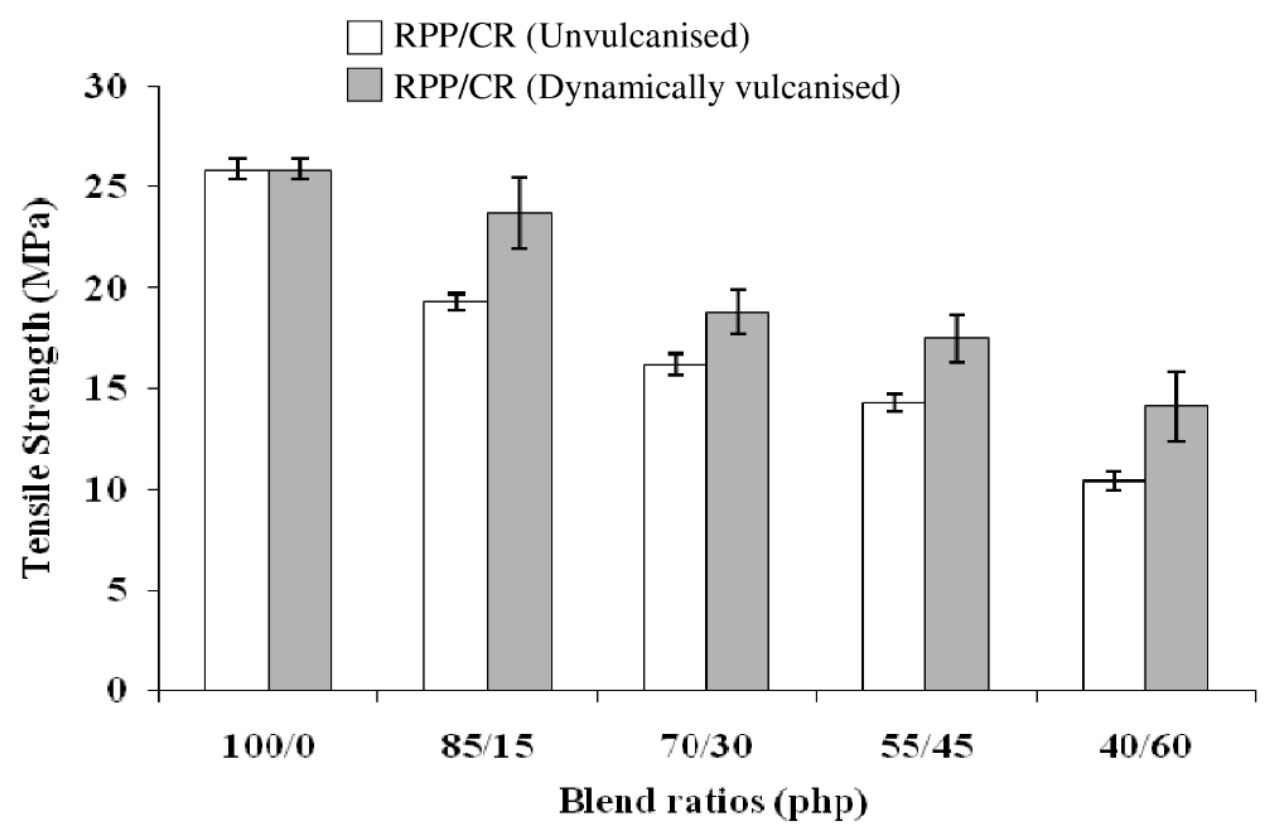

Figure 1: Effect of blend ratios on tensile strength of unvulcanised and dynamically vulcanised RPP/CR blends.

Figure 2 illustrates the effect of blend ratios on Young's modulus of the unvulcanised and dynamically vulcanised RPP/CR blends. It is apparent that Young's modulus of both blends decreased with increasing CR content due to a reduced stiffness of the blends. At similar blend ratios, the dynamically vulcanised RPP/CR blends exhibited a higher Young's modulus than the unvulcanised RPP/CR blends. This suggests the presence of crosslinks in the CR phase since there was an improved stiffness of the dynamically vulcanised $\mathrm{RPP} / \mathrm{CR}$ blends. Accordingly, the Young's modulus is dependent on the crosslink density, and the increase in the crosslink density is reflected by the enhancement in the Young's modulus under dynamic vulcanisation. 


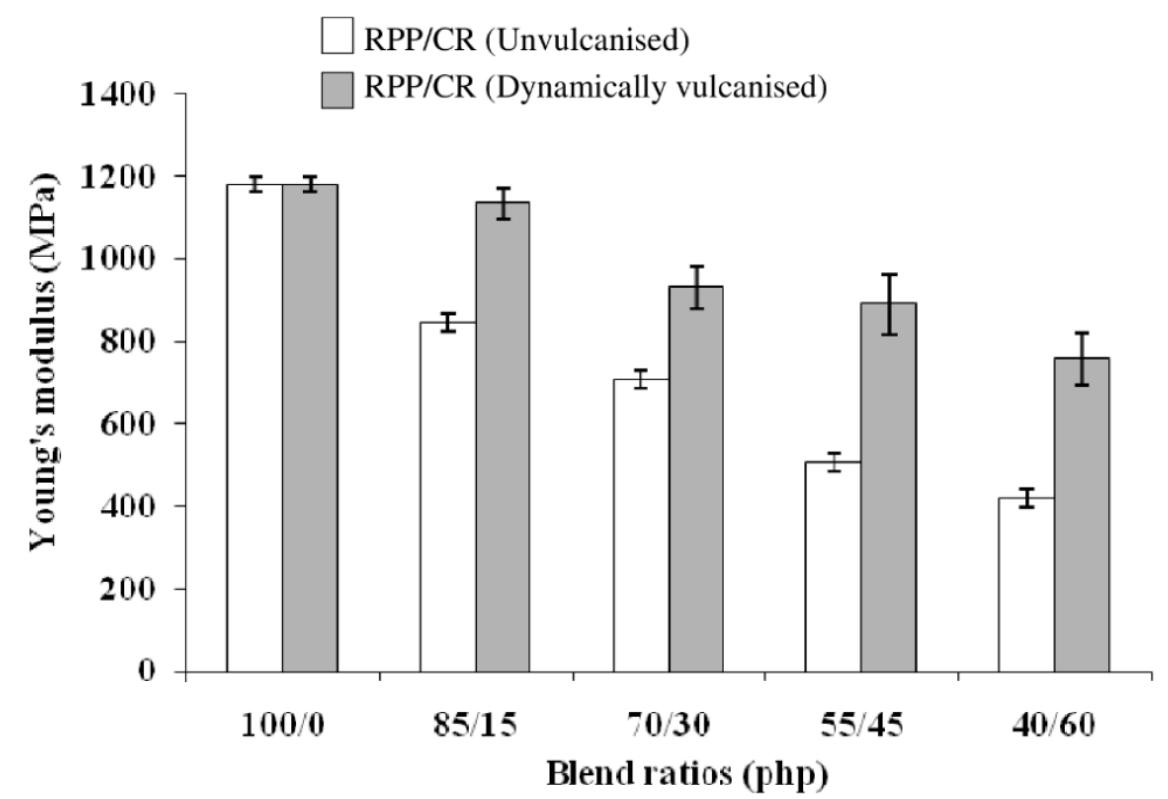

Figure 2: Effect of blend ratios on Young's modulus of unvulcanised and dynamically vulcanised RPP/CR blends.

Figure 3 shows the elongation at break of the unvulcanised and dynamically vulcanised RPP/CR blends with different blend ratios. It was observed that the elongation at break increased with the increasing CR content. Nakason et al. ${ }^{16}$ claimed that the tendency towards recovery to the original shape of elongated samples is higher for the blends with a higher content of CR. Therefore, the dynamically vulcanised RPP/CR blends exhibited a higher elongation at the break in compared to the unvulcanised RPP/CR blends. The improvement of elongation at the break of the dynamically vulcanised blends was due to an improved dispersion of the CR particles in the RPP matrix. Dearmitt ${ }^{17}$ reported that the improved dispersion would help to prevent agglomeration and consequently to maintain a superior elongation at break. The dynamic vulcanisation of TPEs has been previously reported. ${ }^{18-21}$ 


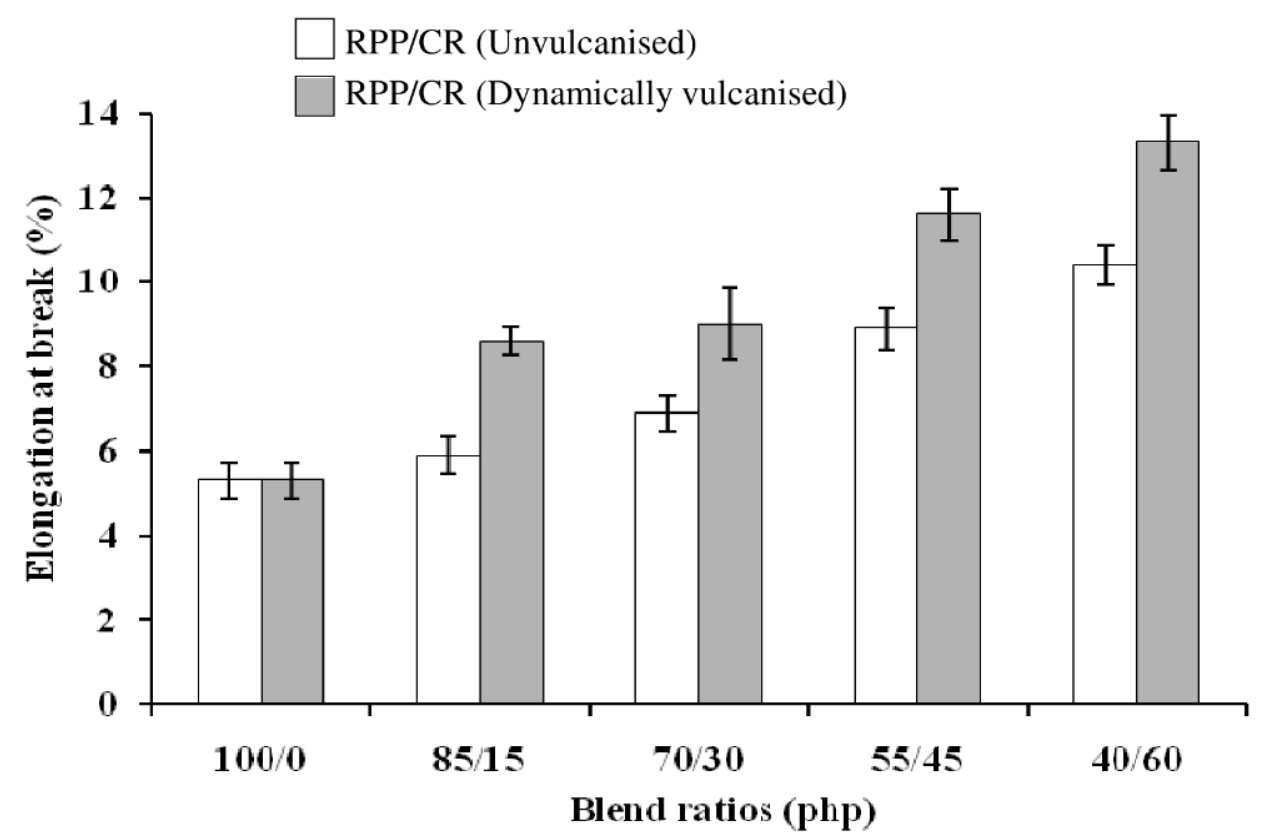

Figure 3: Effect of blend ratios on elongation at break of unvulcanised and dynamically vulcanised RPP/CR blends.

\subsection{Swelling Properties}

Figure 4(a) shows the effect of blend ratios on the swelling percentage of unvulcanised and dynamically vulcanised RPP/CR blends at compositions of $100 / 0,70 / 30$ and $40 / 60$ in toluene for $72 \mathrm{~h}$. The swelling percentage is an indicator of the degree of crosslinking. It can be observed that the swelling percentage of dynamically vulcanised RPP/CR blends was lower than the unvulcanised blends. This indicated that the resistance to chemical penetration of the dynamically vulcanised RPP/CR blends was higher compared to the unvulcanised RPP/CR blends. This is due to the presence of crosslinks in the dynamically vulcanised RPP/CR blends, which hindered the penetration of toluene into the RPP/CR blends. Anandhan et al. $^{22}$ claimed that the swelling index of the dynamically vulcanised blends was less than the unvulcanised blends because crosslinks present in the rubber phase of the vulcanised blends limit the transport of solvent molecules into the blends.

The equilibrium swelling percentage of RPP/CR blends is shown in Figure 4(b). The equilibrium swelling percentage of both unvulcanised and dynamically vulcanised RPP/CR blends increased with increasing CR content for all the compositions of the blends. The blends became less stiff and more permeable to 
the toluene as the $\mathrm{CR}$ content increases within the blends. However, the dynamically vulcanised RPP/CR blends exhibited lower equilibrium swelling percentage compared to the unvulcanised blends. This is due to the presence of the crosslinks, which restricted the penetration of toluene in RPP/CR blends. Similar findings were reported by Ismail et al., ${ }^{23}$ where they found that the swelling index of dynamically vulcanised $\mathrm{PVCw} / \mathrm{NBR}$ blends were lower than unvulcanised PVCV/NBR and PVCw/NBR blends. This is because the blends become stiffer and less penetrable to chemicals as the crosslink density in dynamically vulcanised PVCw/NBR blends increased.
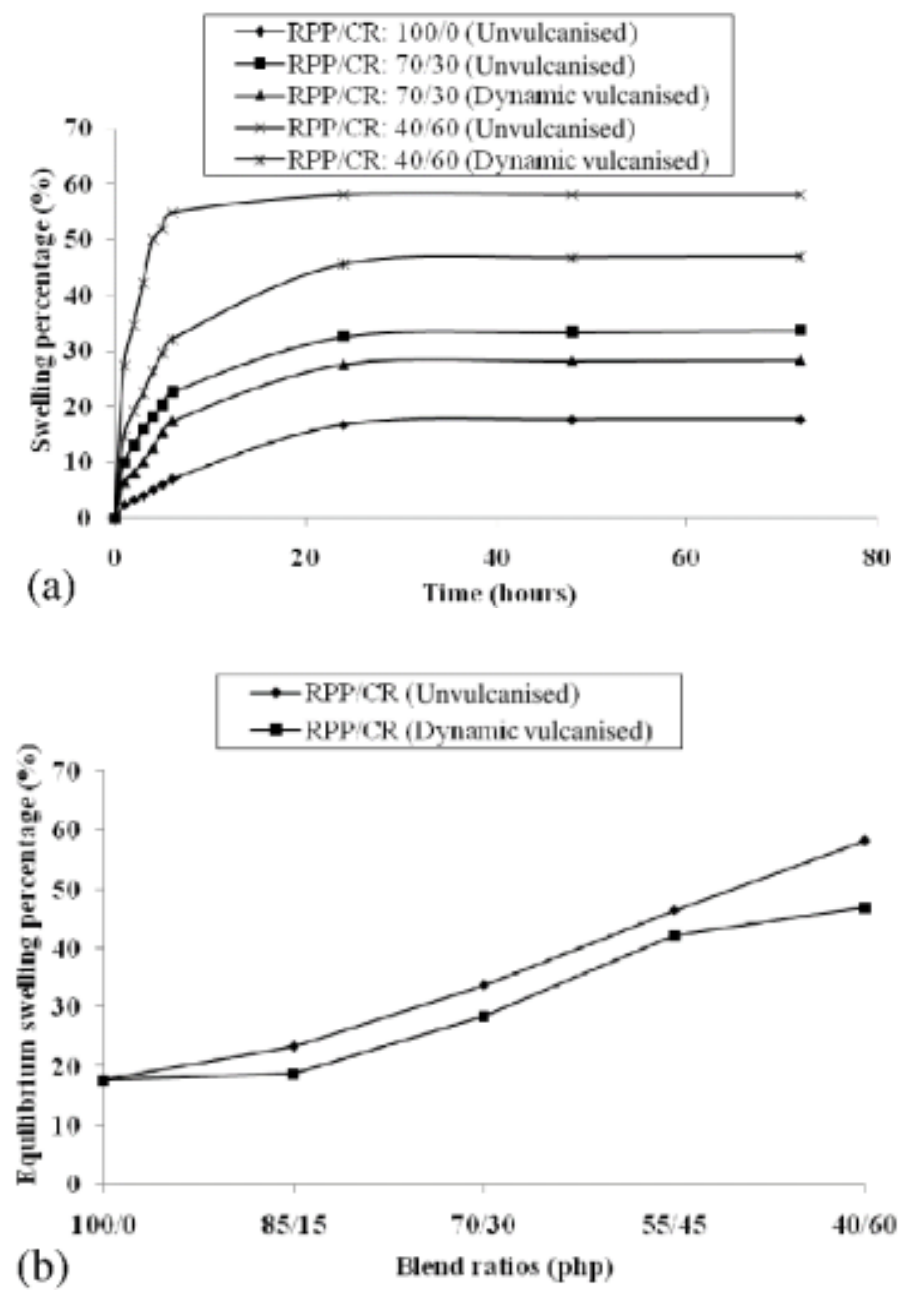

Figure 4: (a) Swelling percentage; and (b) Equilibrium swelling percentage of unvulcanised and dynamically vulcanised RPP/CR blends at different blend ratios. 


\subsection{Morphology Study}

The SEM micrographs of the RPP/CR blends at compositions of 100/0, 70/30 and 40/60 are shown in Figures 5, 6 and 7, respectively. The SEM micrographs of neat RPP show the homogeneous surfaces with a brittle nature, as shown in Figure 5. Figure 6 shows the tensile fractured surfaces of unvulcanised RPP/CR blends at a blend ratio of 70/30, which exhibited a large number of holes formed by the detachment of the CR particles from the RPP matrix due to poor interfacial interaction. Furthermore, the SEM micrographs of the unvulcanised RPP/CR blends at a blend ratio of 40/60 showed larger CR particles dispersed in the RPP matrix (Figure 7). This result indicates that poor interfacial adhesion between the RPP and CR and the agglomeration of CR particles occurs at higher contents of CR. In contrast, the SEM micrographs of the dynamically vulcanised RPP/CR blends at 70/30 and 40/60 are displayed in Figures 8 and 9, respectively. It can be observed that both of SEM micrographs for the dynamically vulcanised RPP/CR blends exhibited CR particles that are better dispersed in the RPP matrix compared to unvulcanised RPP/CR blends, as well as have fewer holes on the RPP surface. This is because the dynamic vulcanisation of TPEs caused the CR particles to be more uniformly dispersed in the RPP matrix and thus enhanced the tensile strength of the TPEs, as discussed in Section 3.1. Kumar et al. ${ }^{24}$ claimed that during dynamic vulcanisation, the crosslinked rubber becomes more finely and uniformly distributed in the plastic matrix. Martin et al. ${ }^{25}$ reported that the dynamic crosslink of the elastomer in molten thermoplastics leads to a very fine and homogeneous morphology, resulting in an improvement of the tensile properties.

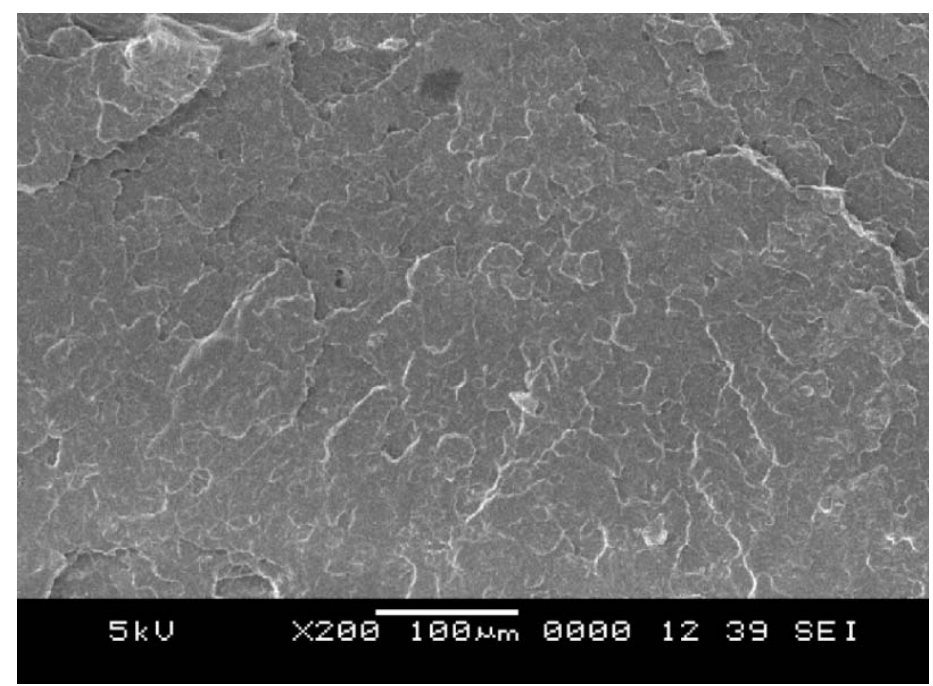

Figure 5: SEM micrograph of neat RPP. 


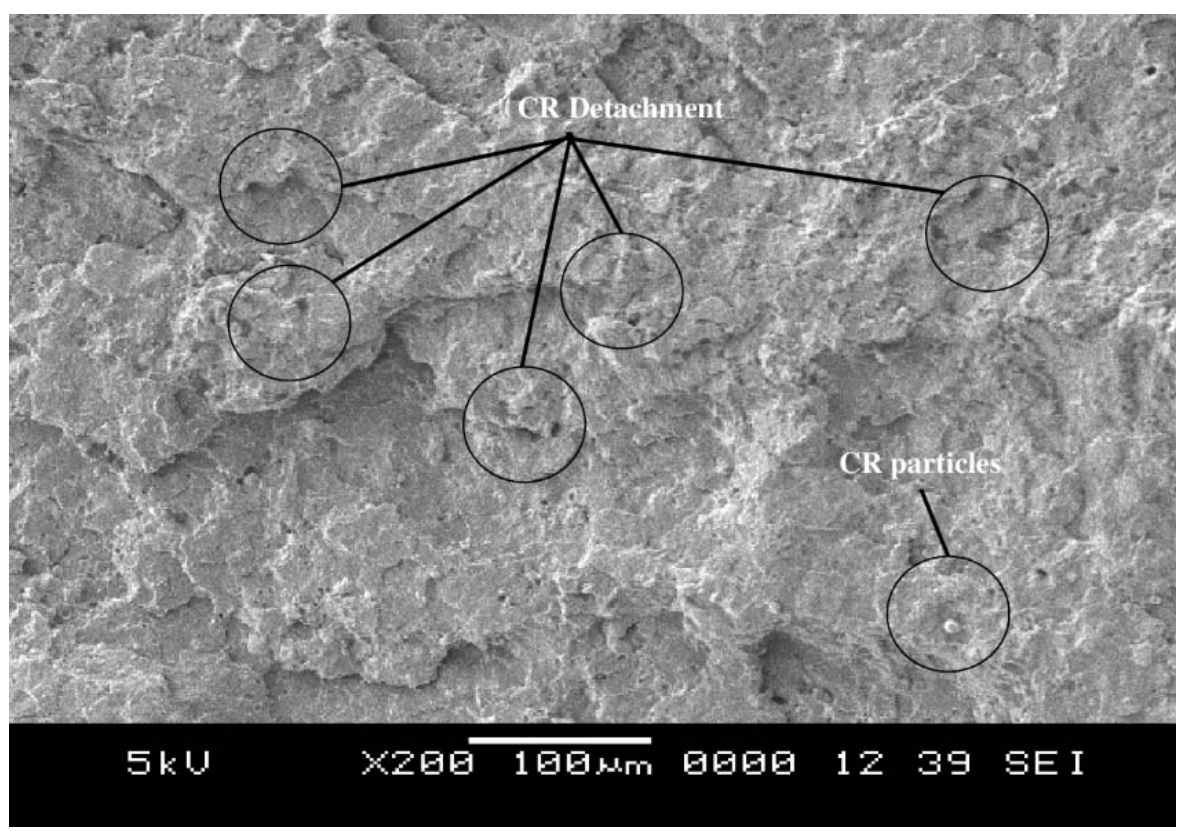

Figure 6: SEM micrograph of unvulcanised RPP/CR (70/30) blend content.

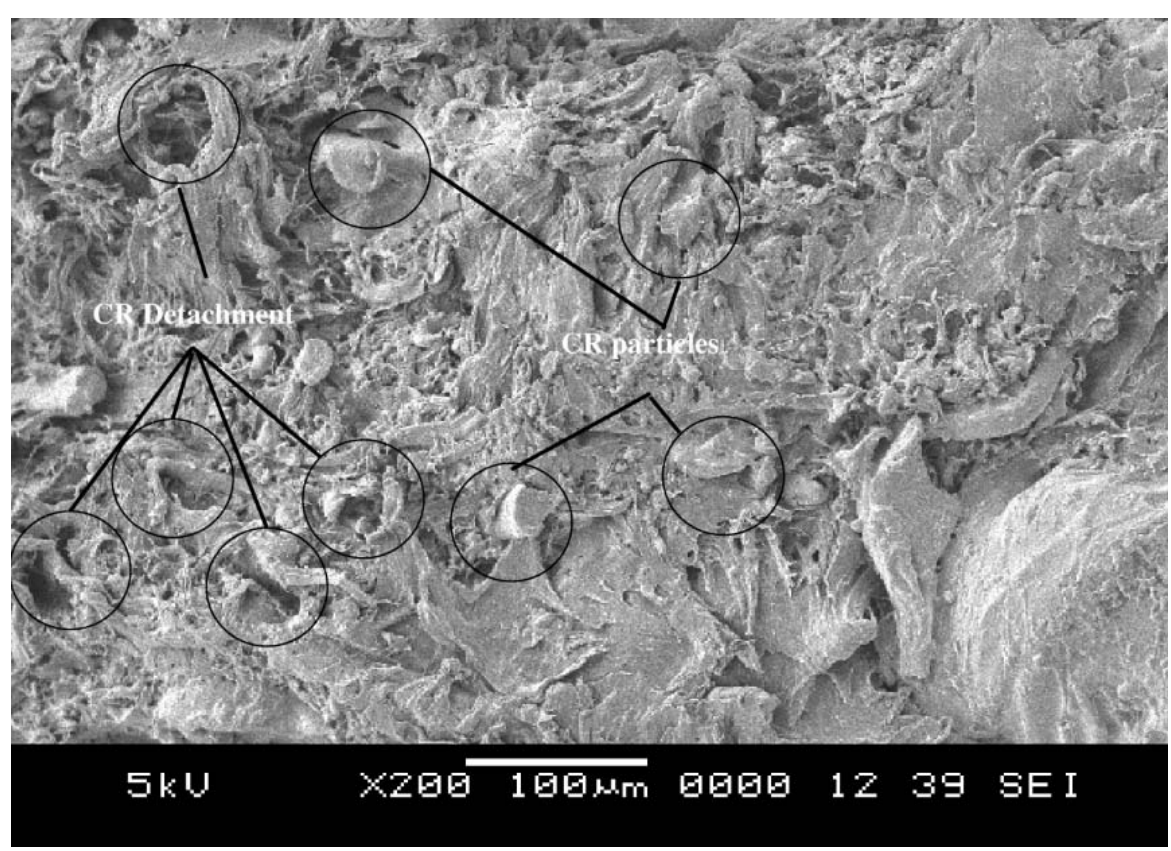

Figure 7: SEM micrograph of unvulcanised RPP/CR (40/60) blend. 


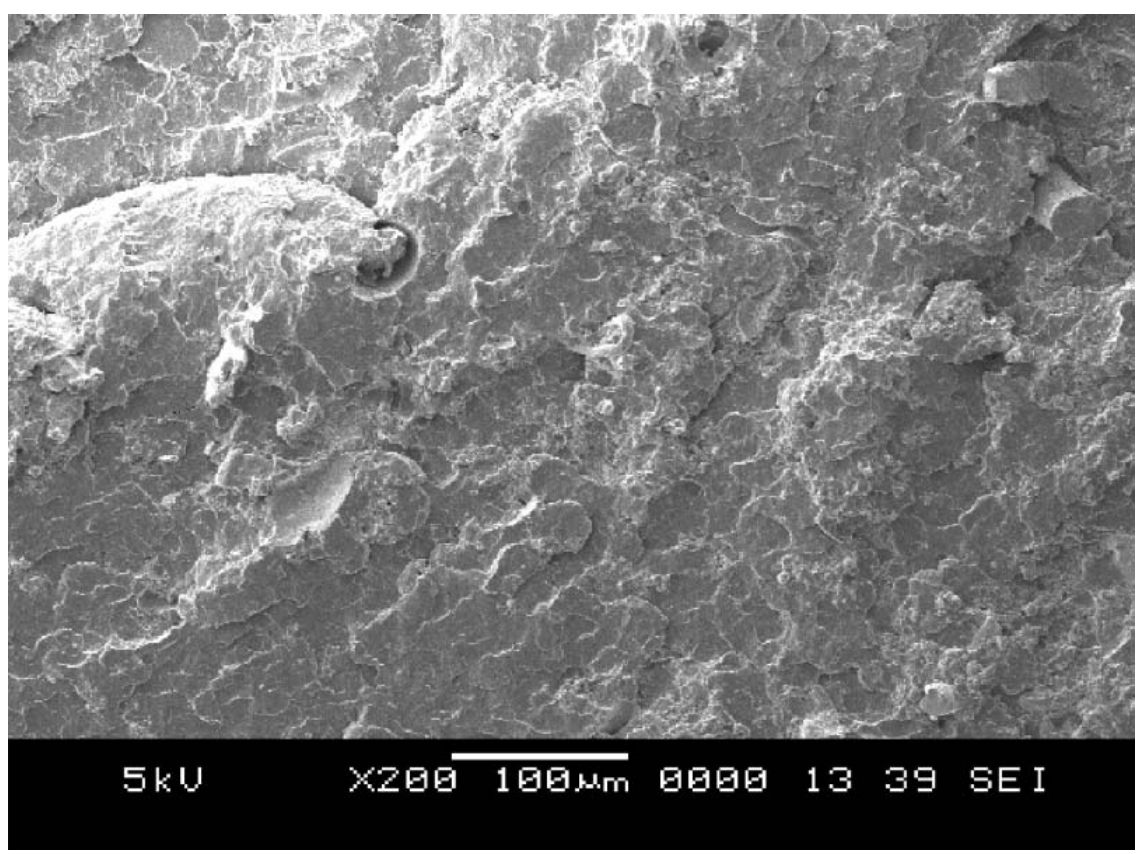

Figure 8: SEM micrograph of dynamically vulcanised RPP/CR (70/30) blend.

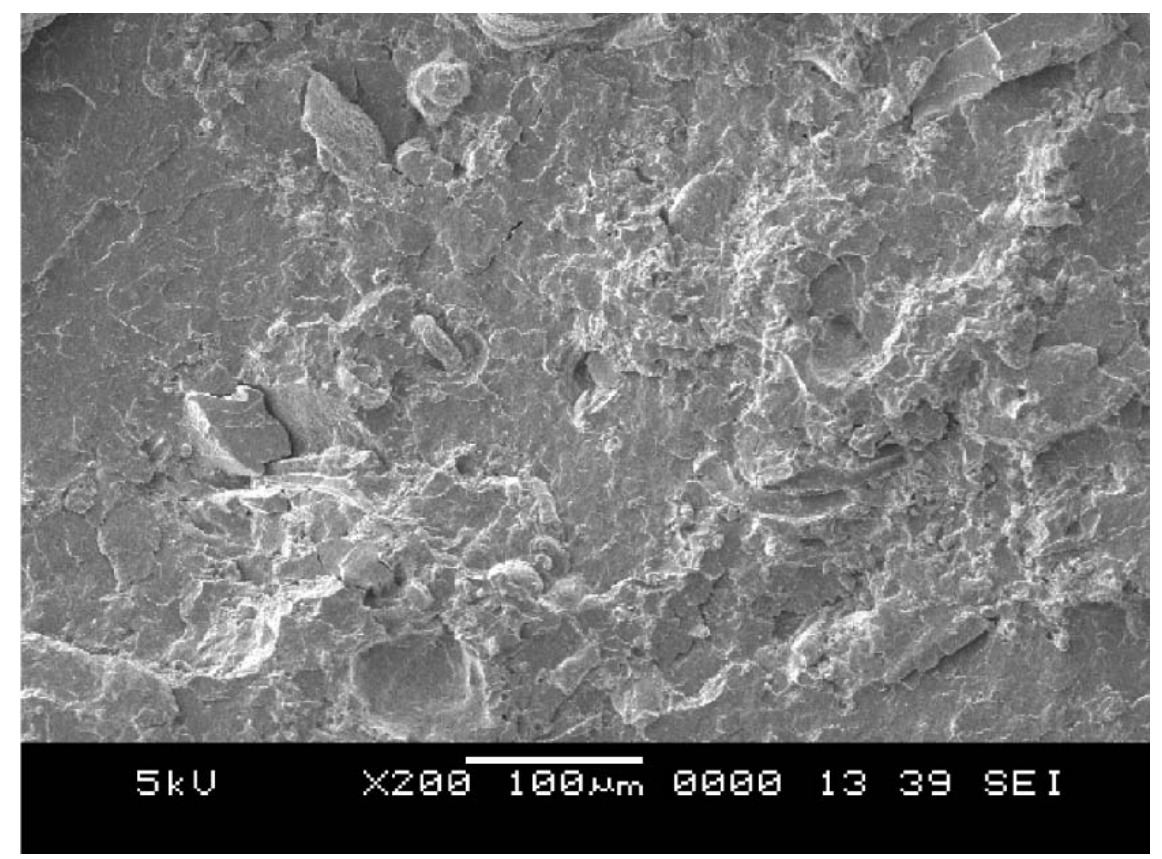

Figure 9: SEM micrograph of dynamically vulcanised RPP/CR (40/60) blend. 


\subsection{Differential Scanning Calorimetry (DSC)}

The DSC curves of unvulcanised and dynamically vulcanised RPP/CR blends at compositions of 100/0 and 40/60 are presented in Figure 10. Table 2 summarises the DSC data of unvulcanised and dynamically vulcanised RPP/CR blends at different blend ratios. In Table 2 , it is shown that the values of $\Delta \mathrm{H}_{\mathrm{f}}$, and $\mathrm{X}_{\mathrm{b}}$ for both the unvulcanised and dynamically vulcanised RPP/CR blends decreased with the increasing $\mathrm{CR}$ content. The inclusion of $\mathrm{CR}$ into the blends limits the crystallising tendency of the RPP and thereby reduced the $\Delta \mathrm{H}_{\mathrm{f}}$ and $\mathrm{X}_{\mathrm{b}}$ of the blends. Nevertheless, the dynamically vulcanised RPP/CR blends exhibited slightly higher values of $\mathrm{T}_{\mathrm{m}}, \Delta \mathrm{H}_{\mathrm{f}}$ and $\mathrm{X}_{\mathrm{b}}$ compared to the unvulcanised $\mathrm{RPP} / \mathrm{CR}$ blends. This indicated that the formation of crosslinks in the dynamically vulcanised RPP/CR blends enhanced the melting and crystallisation behaviour. The crosslinked CR phase held the structure of the blends more firmly together and improved the crystallite stability, as well as raised the melting temperature compared to unvulcanised blends. A similar result was reported by Hernández et al., ${ }^{26}$ who reported that the dynamic vulcanisation of PP/NR blends exhibited a higher $\Delta \mathrm{H}_{\mathrm{f}}$ compared to unvulcanised and static vulcanised blends. They also claimed that when the blends are dynamically vulcanised, the rubber particle size decreased, and the crystallisation process was less hindered, which caused the enthalpy of fusion of the dynamically vulcanised blends to increase.

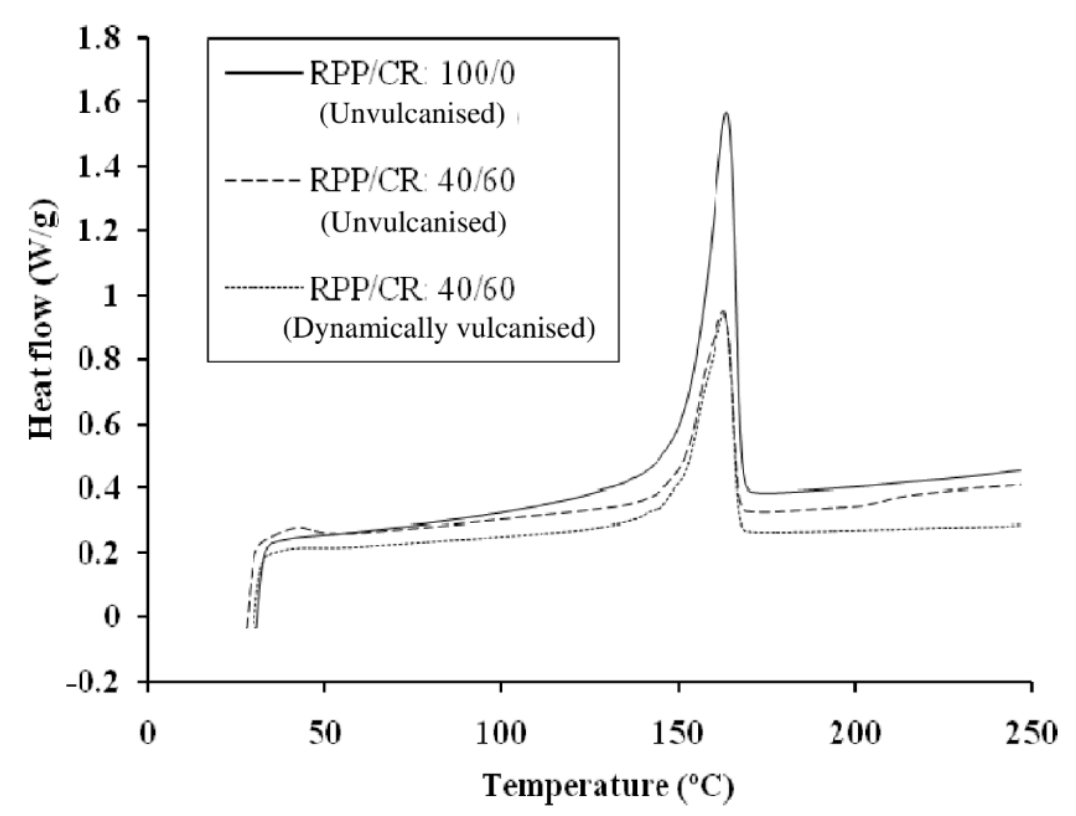

Figure 10: Comparison of DSC curves between RPP, unvulcanised and dynamically vulcanised RPP/CR blends at $60 \mathrm{php}$ of CR content. 
Table 2: The melting temperature $\left(\mathrm{T}_{\mathrm{m}}\right)$, enthalpy of fusion $\left(\Delta \mathrm{H}_{\mathrm{f}}\right)$ and crystallinity $\left(\mathrm{X}_{\mathrm{b}}\right)$ of unvulcanised and dynamically vulcanised RPP/CR blends at different blend ratios.

\begin{tabular}{lccc}
\hline Blends & $\mathrm{T}_{\mathrm{m}}\left({ }^{\circ} \mathrm{C}\right)$ & $\Delta \mathrm{H}_{\mathrm{f}}\left(\mathrm{J} \mathrm{g}^{-1}\right)$ & $\mathrm{X}_{\mathrm{b}}(\%)$ \\
\hline Unvulcanised RPP/CR (100/0) & 164 & 61.40 & 29.4 \\
Unvulcanised RPP/CR (70/30) & 163 & 55.30 & 26.5 \\
Unvulcanised RPP/CR (40/60) & 162 & 44.02 & 21.1 \\
Dynamically vulcanised RPP/CR (70/30) & 165 & 59.10 & 28.3 \\
Dynamically vulcanised RPP/CR (40/60) & 164 & 48.19 & 23.1 \\
\hline
\end{tabular}

\section{CONCLUSION}

Increasing the CR content decreased the tensile strength and Young's modulus of the unvulcanised RPP/CR blends. However, the dynamic vulcanised blends exhibited higher tensile strength, Young's modulus and elongation at the break compared to the unvulcanised blends. The crystallinity of the unvulcanised blends decreased with increasing $\mathrm{CR}$ content, whereas the dynamic vulcanisation showed higher melting temperature $\left(\mathrm{T}_{\mathrm{m}}\right)$, enthalpy $\left(\Delta \mathrm{H}_{\mathrm{f}}\right)$ and crystallinity $\left(\mathrm{X}_{\mathrm{b}}\right)$ compared to the unvulcanised RPP/CR blend. The dynamic vulcanised RPP/CR blends were more resistant to swelling in toluene compared to unvulcanised blends due to the presence of crosslinks within the CR chain.

\section{REFERENCES}

1. Chakraborty, P. et al. (2008). Effect of liquid additives on morphology and properties of thermoplastic elastomers prepared from phase-modified EPDM elastomer and isotactic polypropylene blends. J. Mater. Sci., 43(18), 6167-6176, http://dx.doi.org/10.1007/s10853-008-2930-5.

2. Brachet, P. et al. (2008). Modification of mechanical properties of recycled polypropylene from post-consumer containers. Waste Manage., 28(12), 2456-2464, http://dx.doi.org/10.1016/j.wasman.2007.10.021.

3. Gahleitner, M. et al. (2002). Post-crystallization and physical ageing of polypropylene: Material and processing effects. J. Macromol. Sci. B, 41(4-6), 833-849, http://dx.doi.org/ 10.1081/MB-120013068.

4. Chun, K. S., Salmah, H. \& Azizi, F. N. (2013). Characterization and properties of recycled polypropylene/coconut shell powder composites: Effect of sodium dodecyl sulfate modification. Polym. Plast. Technol. Eng., 52, 287-294, http://dx.doi.org/10.1080/03602559.2012.749282. 
5. Husseinsyah, S., Yeng, C. M. \& Ken, P. W. (2015). Tensile properties of recycled polypropylene (rPP)/chloroprene rubber (CR) blends: Effect of CR content. In Appl. Mech. Mater., 754, 192-196, http://dx.doi.org/ 10.4028/www.scientific.net/AMM.754-755.192.

6. Long, H. (1985). Basic compounding and processing of rubber. Washington: American Chemical Society, Rubber Division.

7. Salmah, H. et al. (2015). A comparative study of polypropylene/ chloroprene rubber and recycled polypropylene/chloroprene rubber blends. J. Vinyl Addit. Technol., 21(2), 122-127.

8. Soto-Oviedo, M. A. \& De Paoli, M. A. (2006). Dynamic vulcanization of thermoplastic elastomers based on poly(epichlorohydrin-co-ethylene oxide) and polypropylene. Polym. Bull., 56(1), 75-85, http://dx.doi.org/ 10.1007/s00289-005-0459-1.

9. Hernández, M. et al. (2008). Fracture behaviour at low strain rate of dynamically and statically vulcanized polypropylene/styrene-butadienestyrene block copolymer blends. Polym. Test, 27(7), 881-885, http://dx.doi.org/10.1016/j.polymertesting.2008.07.005.

10. Ismail, H., Salmah, H. \& Nasir, M. (2001). Dynamic vulcanization of rubber wood-filled polypropylene/natural rubber blends. Polym. Test, 20(7), 819-823, http://dx.doi.org/10.1016/S0142-9418(01)00010-1.

11. Ismail, H., Salmah, H. \& Nasir, M. (2003). The effect of dynamic vulcanization on mechanical properties and water absorption of silica and rubber wood filled polypropylene/natural rubber hybrid composites. Int. J. Polym. Mater., 52(3), 229-238, http://dx.doi.org/10.1080/ 00914030304892.

12. Salmah, H., Ismail, H. \& Abu Bakar, A. (2008). The effects of dynamic vulcanization and compatibilizer on properties of paper sludge filled polypropylene (PP)/ethylene propylenediene terpolymer (EPDM) composites. J. Appl. Polym. Sci., 107, 2266-2273, http://dx.doi.org/ 10.1002/app.27367.

13. Chun, K. S., Husseinsyah, H. \& Yeng, C. M. (2015). Green composites from kapok husk and recycled polypropylene: Processing torque, tensile, thermal, and morphological properties. J. Thermoplast. Compos. Mater., http://dx.doi.org/10.1177/0892705715569822.

14. Van Dyke, J. D. et al. (2003). A study of dynamic vulcanization for polyamide-12 and chlorobutyl rubber. J. Appl. Polym. Sci., 90(3), 871880, http://dx.doi.org/10.1002/app.12529.

15. Narathichat, M. et al. (2011). Thermoplastic natural rubber based on polyamide-12: Influence of blending technique and type of rubber on temperature scanning stress relaxation and other related properties. J. Appl. Polym. Sci., 121(2), 805-814. 
16. Nakason, C. et al. (2006). Dynamic vulcanization of natural rubber/highdensity polyethylene blends: Effect of compatibilization, blend ratio and curing system. Polym. Test., 25(6), 782-796, http://dx.doi.org/10.1016/ j.polymertesting.2006.05.001.

17. Dearmitt, C. (2011). Applied plastics engineering handbook. New York: Elsevier.

18. Wang, Z., Zhang, X. \& Zhang, Y. (2002). Impact properties of dynamically vulcanized nylon/styrene-acrylonitrile copolymer/nitrile rubber blends. Polym. Test., 21(5), 577-582, http://dx.doi.org/ 10.1016/S0142-9418(01)00127-1.

19. Liu, X. et al. (2003). EPDM/polyamide TPV compatibilized by chlorinated polyethylene. Polym. Test., 22(1), 9-16, http://dx.doi.org/ 10.1016/S0142-9418(02)00035-1.

20. Soares, B. G. et al. (2007). The characterization of PP/NBR blends by positron annihilation lifetime spectroscopy (PALS): The effect of composition and dynamic vulcanization. Polym. Test., 26(1), 88-94, http://dx.doi.org/10.1016/j.polymertesting.2006.08.009.

21. Tang, X. G. et al. (2009). Effect of $\beta$-phase on the fracture behavior of dynamically vulcanized PP/EPDM blends studied by the essential work of fracture approach. Eur. Polym. J., 45(5), 1448-1453, http://dx.doi.org/ 10.1016/j.eurpolymj.2009.02.004.

22. Anandhan, S. et al. (2009). Thermal degradation and swelling of thermoplastic vulcanizates from NBR/SAN and NBR/scrap computer plastics blends. Kautschuk Gummi Kunststoffe, 62, 529-536.

23. Ismail, H., Supri, A. \& Yusof, A. M. M. (2004). Properties of virgin poly(vinylchloride)/acrylonitrile butadiene rubber (PVCv/NBR) and waste poly(vinylchloride)/acrylonitrile butadiene rubber (PVCw/NBR) blends: The effect of blend composition and dynamic vulcanization. Polym. Plast. Technol. Eng., 43(3), 695-711, http://dx.doi.org/ 10.1081/PPT-120038060.

24. Kumar, C. R., Fuhrmann, I. \& Karger-Kocsis, J. (2002). LDPE-based thermoplastic elastomers containing ground tire with and without dynamic curing. Polym. Degrad. Stab., 76(1), 137-144, http://dx.doi.org/10.1016/S0141-3910(02)00007-1.

25. Martin, G. et al. (2009). Morphology development in thermoplastic vulcanizates (TPV): Dispersion mechanisms of a pre-crosslinked EPDM phase. Eur. Polym. J., 45(11), 3257-3268, http://dx.doi.org/10.1016/ j.eurpolymj.2009.07.012.

26. Hernández, M. et al. (2006). Influence of type of vulcanization on rheological and thermal properties of PP/NR blends. Polym. Bull., 56(2-3), 285-291, http://dx.doi.org/10.1007/s00289-005-0481-3. 